УДК 796.015.035 / 373.6.

https://doi.org/10.52058/2786-4952-2022-2(7)-231-240

Голяка Сергій Кіндратович кандидат біологічних наук, доцент, Херсонський державний університет, вул. Університетська, 27, м. Херсон, 73000, тел.: (0552) 32-67-65, https://orcid.org/0000-0001-6805-584X

Кім Роберт Артурович магістр 3 фізичного виховання, Херсонський державний університет, вул. Університетська, 27, м. Херсон, 73000, тел.: (0552) 32-67-65

Коваль Вікторія Юріївна кандидат педагогічних наук, доцент, Херсонський державний університет, вул. Університетська, 27, м. Херсон, 73000, тел.: (0552) 32-67-65, https://orcid.org/0000-0003-0550-8631

Кольцова Ольга Сергіївна кандидат педагогічних наук, доцент, Херсонський державний університет, вул. Університетська, 27, м. Херсон, 73000, тел.: (0552) 32-67-65, https://orcid.org/0000-0002-4817-7812

\title{
ДОСЛІДЖЕННЯ ВПЛИВУ ЗАНЯТЬ КРОСФІТОМ НА ФІЗИЧНИЙ РОЗВИТОК ТА СИЛОВУ ПІДГОТОВЛЕНІСТЬ СТАРШОКЛАСНИКІВ
}

Анотація. Вдосконалення фізичного розвитку та фізичної підготовленості, зокрема силової підготовленості учнівської та студентської молоді може відбуватися у випадку систематичних на цілеспрямованих занять фізичним вихованням.

Силова підготовленість як складова частина загальної фізичної підготовленості, фізичний розвиток учнів та студентів останнім часом погіршується, що передбачає перегляд загальноприйнятої системи фізичного виховання. Постійний пошук сучасних найбільш ефективних засобів фізичного виховання, організація шкільних секцій відіграє важливе значення для підвищення мотивації учнів до систематичних занять фізичною культурою.

Стан організаційно-методичного забезпечення занять 3 фізичного виховання не дозволяє в повній мірі, вирішувати питання організації та їх реалізації під час секційних позаурочних занять із кросфіту з учнями вищої професійної освіти.

3 метою визначення впливу занять кросфітом на рівень силової підготовленості та фізичного розвитку юнаків проведено дослідження на базі Державного навчального закладу «Вище професійне училище №2 м. Херсона». У обстеженні прийняли участь 33 учні старших класів, з яких були сформовані експериментальна група із юнаків, котрі займалися в позаурочній секції 3 кросфіту на базі спортивної зали училища та юнаки контрольної групи. 
Встановлено, що після впровадження секційних занять кросфітом відбувається достатній приріст всіх показників силової підготовленості в юнаків експериментальної групи (на 14,6\%-24,8\%) порівняно 3 показниками юнаків контрольної групи (лише до 2,3\%). Середні показники рівня силової підготовленості юнаків експериментальної групи на другому етапі обстеження у всіх випадках достовірно відрізняються від аналогічних показників першого етапу обстеження.

Фізичні навантаження на тренуваннях із кросфіту сприяють покращенню показника життєвого індексу на $8,8 \%$, показника силового індексу на $11,9 \%$ та показника індексу Руф'є на 12,7\%. Достовірні різниці між показниками першого та другого етапів обстеження у групі юнаків експериментальної групи спостерігалися за силовим індексом та індексом Руф'є.

Ключові слова: кросфіт, силова підготовленість, фізичний розвиток, старшокласники.

Holiaka Serhii Kindratovych Ph.D. of Biological sciences, Associate Professor, Kherson State University, Universytetska St., 27, Kherson, 73000, tel.: (0552) 32-67-65, https://orcid.org/0000-0001-6805-584X

Kim Robert Arturovich Master's Degree Physical Education, Kherson State University, Universytetska St., 27, Kherson, 73000, tel.: (0552) 32-67-65

Koval Viktoriia Yuriivna Ph.D. of Pedagogic Sciences, Associate Professor, Kherson State University, Universytetska St., 27, Kherson, 73000, tel.: (0552) 32-67-65, https://orcid.org/0000-0003-0550-8631

Koltsova Olha Serhiivna Ph.D. of Pedagogic Sciences, Associate Professor, Kherson State University, Universytetska St., 27, Kherson, 73000, tel.: (0552) 32-67-65, https://orcid.org/0000-0002-4817-7812

\section{STUDY OF THE INFLUENCE OF CROSSFIT EXERCISES ON PHYSICAL DEVELOPMENT AND STRENGTH PREPAREDNESS OF HIGH SCHOOL STUDENTS}

Abstract. Improvement of physical development and physical fitness, in particular of strength pupils and students, can take place in the case of systematic and purposeful physical education classes.

Strength training as an integral part of general physical fitness, physical development of pupils and students has recently deteriorated, which involves a revision of the generally accepted system of physical education. The constant search for the most modern means of physical education, the organization of school sections is important to increase students' motivation for regular physical education. 
The state of organizational and methodological support of physical education classes does not allow to fully address the issues of organization and implementation during sectional extracurricular crossfit classes with students of higher professional education.

In order to determine the impact of crossfit classes on the level of strength training and physical development of young people, a study was conducted on the basis of the State Educational Institution "Higher Vocational School №2 Kherson". The survey was attended by 33 high school students, from which an experimental group of young men was formed, who were engaged in extracurricular crossfit section on the basis of the school gym and young men of the control group.

It was found that after the introduction of cross-sectional crossfit classes there is a sufficient increase in all indicators of strength training in young men of the experimental group $(14.6 \%-24.8 \%)$ compared with young men in the control group (only $2.3 \%$ ). The average indicators of the level of strength training of young men in the experimental group at the second stage of the survey in all cases differ significantly from similar indicators of the first stage of the survey.

Exercise in crossfit training improves the life index by $8.8 \%$, the strength index by $11.9 \%$ and the Rufier index by $12.7 \%$. Significant differences between the indicators of the first and second stages of the survey in the group of young men of the experimental group were observed by the strength index and the Rufier index.

Keywords: crossfit, strength training, physical development, high school students.

Постановка проблеми. Останнім часом погіршується рівень фізичної підготовленості, зокрема силової підготовленості учнівської та студентської молоді, що може бути викликано, на думку учених, недостатньою їх руховою активністю, недостатньої кількості навчальних годин та не ефективністю діючої системи фізичного виховання.

Проблема фізичної підготовки учнів та студентів представляє інтерес у зв'язку із вираженими змінами соціально-економічних і екологічних умов життя суспільства. Тому розробка загальних методичних рекомендацій і широке застосування різних методів базової фізичної, зокрема силової, підготовки, утримується дефіцитом наукових досліджень у цьому напрямку.

Аналіз останніх досліджень і публікацій. Питанням вдосконалення фізичної підготовленості та фізичного розвитку учнівської та студентської молоді під час занять кросфітом присвячені роботи

Базилевич Н.О., Тонконога О.С. (2016), Бесараба Т., Герасімова О. (2015), Кіма Р.А. (2020), Кокорєва, Д. А., Випрікова Д.В., Везеніцина О.В., Бодрова І.М. (2016), Петрової А. (2021) та інших [1-4, 6].

На думку вчених, застосування різних новітніх підходів у фізичному вихованні учнівської та студентської молоді сприятиме всебічному розвитку в них фізичних, а також психічних якостей $[1-4,6]$. Кросфіт, як сучасний вид спорту, повинен стати тим важливим необхідним стимулом до систематичного відвідування і проведення занять учнями і студентами фізичною культурою та 
спортом, сприятиме розвитку в них силових якостей, вдосконаленню їх фізичного розвитку $[1-4,6]$.

Слід відмітити, що застосування засобів кросфіту у сприянні адекватного фізичного розвитку і силової підготовленості учнівської та студентської молоді дозволить зміцненню їх здоров’я та підвищення рівня їх рухової активності [4].

Мета статті - дослідити особливості фізичного розвитку та рівня силової підготовленості учнів старшого шкільного віку, які займаються у позаурочний час в секції кросфіту.

Виклад основного матеріалу. Дослідження проводилось на базі ДНЗ «ВПУ №2 м. Херсона». У обстеженні прийняли участь 33 учні старших класів училища, 3 яких було сформовано дві групи: експериментальна група (ЕГ) 3 юнаків, які займалися в позаурочній секції з кросфіту на базі спортивної зали училища, у кількості 12 осіб (з яких по 6 юнаків 311 класу та 1 курсу) та контрольна група (КГ) з 21 особи (з яких 12 юнаків 11 класу та 9 юнаків 1 курсу). Обстеження також проводилося двічі: у вересні 2020 року та у листопаді 2020 року.

Юнаки ЕГ займалися в секції 3 кросфіту за розробленою методикою розвитку силових якостей двічі на тиждень по 90 хв та відвідували одне заняття 3 фізичного виховання за розкладом. КГ учнів (студентів) займалися за загальноприйнятою системою фізичного виховання за розкладом і два заняття на тиждень у позанавчальний час в секції загальної фізичної підготовки, що передбачено навчальною програмою училища.

Ефективність запропонованої нами методики підвищення рівня силової підготовленості (СП) у юнаків засобами кросфіту у групах обстеження ЕГ оцінювалася за результатами тестування (підтягування на перекладині; згинання та розгинання рук в упорі лежачи; піднімання тулуба в сід за 30 с; визначення сили кисті) та ряду індексів фізичного розвитку (IФР) (життєвий та силовий індекс, індекс Руф'є) [5].

При розробці методики тренувань використовувалися практичні рекомендації науковців 3 даного виду фізичного виховання $[1,2,3,4]$.

Як ми відмічали раніше (Кім Р.А., 2020), основою програми силових занять i3 використанням засобів кросфіту було кондиційне тренування, iз застосуванням фізичних навантажень різної інтенсивності. Під час занять 3 кросфіту в спортивній залі училища нами постійно застосовувався контроль за станом самопочуття юнаків, зокрема за величиною частоти серцевих скорочень при виконанні навантаження [3].

Була розроблена загальна структура тренувальних занять із використання наявних засобів, що використовуються у кросфіті. Виділено підготовчий період під час якого відбувалася адаптація організму юнаків до навантажень 3 кросфіту (2 тижні). У основному періоді застосовували тренувальні заняття 3 кросфіту протягом 2-х місяців та період з використанням традиційних вправ кросфіту: біг на місці, різного характеру присідання, віджимання від підлоги, комплексна вправа «берпі», вистрибування на куб, вправи на прес, випади та інші. Вправи виконували застосовуючи коловий метод тренувань та інтервальний метод. 
Під час кожного з періодів нами було розроблено комплекси вправ різної спрямованості. Ці комплекси вправ складалися 3 врахуванням індивідуального підбору засобів, їх цільового спрямування, оптимального поєднання засобів на заняттях в залежності від поставленої мети.

Під час першого етапу ми застосовували серію вправ, які можна було виконувати без урахування часу, і при цьому надавали можливість робити перерви між вправами (декілька хвилин). Пізніше, коли відмічалася адаптація до занять ми рекомендували виконувати серію вправ за певний встановлений час (15-20 хв) і робити менші перерви між вправами (1-3 хв). Досягнувши досить високого рівня підготовленості юнаки виконували серії вправ за встановлений час вже без перерв (15-20 хв). Протягом тренувального заняття юнаки мають здійснити як можна більше подібних серій. На початку тренувань між серіями дозволялося робити відпочинок до 5-7 хвилин. Час тривалості кожної серії становив 5-10 хвилин [1-4].

Під час підбору фізичних вправ враховувався фактор задіяння за можливістю більшість м'язових груп. Співвідношення частин заняття становило: розминка - 15-20 хв, основна частина заняття - 45-50 хв і заключна частина заняття - 10-15 хв. Запропонована програма передбачала: раціональний підбір комплексу вправ аеробної та змішаної аеробно-анаеробної спрямованості; дотримання режиму проведення занять, величини інтенсивності та обсягу фізичних навантажень; контроль за динамікою показників визначення фізичного стану організму. Заняття проводилося три рази на тиждень. Після періоду адаптації організму юнаків через кожні 2 тижні регулярних занять ми змінювали програму [1-4].

Контроль за ефективністю впровадженої методики здійснювався після двох місяців систематичних тренувань у секції кросфіту ЕГ обстежуваних. ЕГ юнаків була сформована згідно їх бажання займатися в секції з кросфіту.

Результати дослідження силової підготовленості та індексів фізичного розвитку представлені у таблицях.

3 даних таблиці 1 видно, що на початку експерименту середні показники підтягування на перекладині виявилися вищими в юнаків ЕГ і становили 9,3 $\pm 0,6$ рази, хоча вони виявилися не достовірними $(\mathrm{t}=0,64, \mathrm{p}>0,05)$ від показників юнаків КГ, в яких середній показник становив $8,8 \pm 0,5$ разів.

Наступним завданням було проаналізувати рівень розвитку силових якостей за цим тестом наприкінці експерименту. Можна відмітити, що у обох групах юнаків спостерігається зростання показників у підтягуванні на перекладині: на 20,4\% у групі юнаків, які займаються кросфітом та на 2,3 \% в юнаків КГ. Середні показники юнаків, які займалися кросфітом становили $11,2 \pm 0,6$ рази, а в юнаків КГ - 9,0 $\pm 0,6$ разів. Отримані середні показники обох груп між собою достовірно відрізнялися $\mathrm{t}=2,62, \mathrm{p}>0,05$.

Ми виявили достовірні відмінності між показниками підтягування на перекладині I та II етапів лише у юнаків ЕГ $(\mathrm{t}=2,26, \mathrm{p}<0,05)$. 
Аналізуючи отримані результати дослідження СП, що здійснювалося за виконанням вправи «Згинання і розгинання рук в упорі лежачи» у обох групах дослідження ми також спостерігаємо їх позитивну динаміку. Хоча середні показники у ЕГ обстежуваних більш суттєво покращилися за період проведення дослідження, ніж у КГ юнаків.

Таблиия 1.

Порівняльна характеристика показників силової підготовленості юнаків

\begin{tabular}{|c|c|c|c|c|c|}
\hline \multirow{2}{*}{$\begin{array}{l}\text { Етапи } \\
\text { дослідження }\end{array}$} & \multicolumn{2}{|l|}{$\mathbf{E \Gamma}$} & \multicolumn{2}{|l|}{$\mathbf{K} \boldsymbol{\Gamma}$} & \multirow[t]{2}{*}{ Вірогідність } \\
\hline & $\mathrm{X} \pm \mathrm{m}$ & 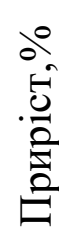 & $\mathrm{X} \pm \mathrm{m}$ & 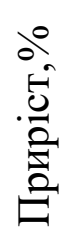 & \\
\hline
\end{tabular}

Підтягування та перекладині, рази

\begin{tabular}{|l|l|l|l|l|l|}
\hline Вихідні дані & $9,3 \pm 0,6$ & 20,4 & $8,8 \pm 0,5$ & 2,3 & 0,64 \\
\cline { 1 - 1 } & & & $9,0 \pm 0,6$ & & 2,62 \\
\hline Кінцеві дані & $11,2 \pm 0,6$ & & 0,26 & & \\
\hline
\end{tabular}

Згинання та розгинання рук в упорі лежачи, рази

\begin{tabular}{|c|c|c|c|c|c|}
\hline Вихідні дані & $34,2 \pm 1,6$ & \multirow[t]{2}{*}{14,6} & $32,4 \pm 1,4$ & \multirow[t]{2}{*}{1,2} & 0,80 \\
\hline Кінцеві дані & $39,2 \pm 1,6$ & & $32,8 \pm 1,4$ & & 2,96 \\
\hline & 2,21 & & 0,20 & & \\
\hline
\end{tabular}

Піднімання тулуба в сід $3 а 30$ с, рази

\begin{tabular}{|l|l|l|l|l|l|}
\hline Вихідні дані & $21,8 \pm 1,4$ & 24,8 & $21,2 \pm 1,2$ & $-2,8$ & 0,32 \\
\cline { 1 - 2 } & $26,2 \pm 1,3$ & & $20,6 \pm 1,2$ & & 3,18 \\
\hline Кінцеві дані & 2,30 & & 0,36 & & \\
\hline
\end{tabular}

\section{Кистьова динамометрія, кг}

\begin{tabular}{|l|l|l|l|l|l|}
\hline Вихідні дані & $35,8 \pm 1,6$ & 16,7 & $34,2 \pm 1,7$ & 1,2 & 0,68 \\
\cline { 1 - 1 } & & & $34,6 \pm 1,6$ & 2,83 \\
\hline $\mathrm{t}$ & 2,28 & & 0,17 & & \\
\hline
\end{tabular}

Аналізуючи отримані результати дослідження СП, що здійснювалося за виконанням вправи «Згинання і розгинання рук в упорі лежачи» у обох групах дослідження ми також спостерігаємо їх позитивну динаміку. Хоча середні показники у ЕГ обстежуваних більш суттєво покращилися за період проведення дослідження, ніж у КГ юнаків.

Середній показник тесту «Згинання і розгинання рук в упорі лежачи» в

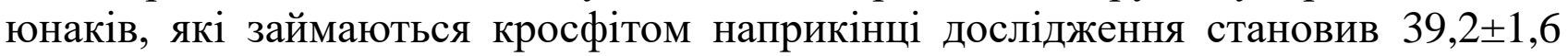
рази, тоді як в КГ - 32,8 $\pm 1,4$ рази $(\mathrm{t}=2,96, \mathrm{p}<0,05)$.

Нами виявлено достовірні відмінності між показниками тесту «Згинання та розгинання рук в упорі лежачи» на початку експерименту та наприкінці його лише у ЕГ обстежуваних $(\mathrm{t}=2,21, \mathrm{p}<0,05)$.

Для більш повної картини впливу методики розвитку силових якостей ми використали тест «Піднімання тулуба в сід за 30 с» та показники кистьової динамометрії. 
3 даних таблиці 1. видно, що на початку експерименту середні в юнаків ЕГ становили $21,8 \pm 1,4$ рази, хоча вони виявилися не достовірними $(\mathrm{t}=0,32, \mathrm{p}>0,05)$ від показників юнаків КГ, в яких середній показник становив $21,2 \pm 1,2$ рази.

На II етапі обстеження можна відмітити, що лише у ЕГ юнаків спостерігається позитивна динаміка у показниках, тоді як в групі юнаків КГ ми, навіть, спостерігали погіршення показника наприкінці обстеження.

Середні показники юнаків, які займаються в секції кросфіту становили $26,2 \pm 1,3$ рази, а у юнаків КГ - 20,6 1,2 рази $(\mathrm{t}=3,18, \mathrm{p}<0,01)$.

Нами також виявлено достовірні відмінності між показниками виконання тесту «Піднімання тулуба в сід за 30 с» в юнаків, які займаються в секції кросфіту I та II етапів тестування $(\mathrm{t}=2,30, \mathrm{p}<0,05)$.

Показники кистьової динамометрії на I етапі обстеження у ЕГ юнаків виявилися дещо вищими (середній показник становив $35,8 \pm 1,6$ кг), ніж у юнаків КГ $(34,2 \pm 1,7$ кг).

Наприкінці дослідження відбувається подальше зростання показників кистьової динамометрії у обох групах. Слід відмітити неоднаковий приріст показників в обох групах. Так, показники кистьової динамометрії в юнаків, які займаються в секції кросфіту покращилися на 16,7\%, тоді як в юнаків КГ лише на $1,2 \%(\mathrm{t}=2,83 \mathrm{p}<0,05)$. Виявлено достовірні відмінності між показниками кистьової динамометрії юнаків ЕГ I та II етапу обстеження $(\mathrm{t}=2,28, \mathrm{p}<0,05)$.

Ми висловлюємо припущення, що систематичні заняття кросфітом позитивно вплинуть на фізичний розвиток юнаків, що цим видом спорту займалися. Дані обстеження представлені у таблиці 2.

Таблиия 2.

Порівняльна характеристика показників індексів фізичного розвитку у юнаків

\begin{tabular}{|c|c|c|c|c|c|}
\hline \multirow{2}{*}{$\begin{array}{l}\text { Етапи } \\
\text { дослідження }\end{array}$} & \multicolumn{2}{|l|}{ EГ } & \multicolumn{2}{|l|}{ КГ } & \multirow[t]{2}{*}{ Вірогідність } \\
\hline & $\mathrm{X} \pm \mathrm{m}$ & $\begin{array}{l}\stackrel{0}{0} \\
\stackrel{0}{0} \\
\stackrel{0}{0} \\
\text { : }\end{array}$ & $\mathrm{X} \pm \mathrm{m}$ & 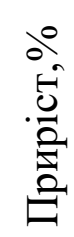 & \\
\hline \multicolumn{6}{|c|}{ Життєвий індекс, мл/кг } \\
\hline Вихідні дані & $52,5 \pm 1,8$ & \multirow[t]{2}{*}{8,8} & $51,8 \pm 1,9$ & \multirow[t]{2}{*}{1,2} & 0,27 \\
\hline Кінцеві дані & $57,1 \pm 1,8$ & & $52,4 \pm 1,9$ & & 1,80 \\
\hline $\mathrm{t}$ & 1,78 & & 0,22 & & \\
\hline \multicolumn{6}{|c|}{ Силовий індекс кисті, \% } \\
\hline Вихідні дані & $51,1 \pm 1,8$ & \multirow[t]{2}{*}{11,9} & $48,1 \pm 1,5$ & \multirow[t]{2}{*}{2,1} & 1,28 \\
\hline Кінцеві дані & $57,2 \pm 1,9$ & & $49,1 \pm 1,6$ & & 3,25 \\
\hline $\mathrm{t}$ & 2,33 & & 0,46 & & \\
\hline \multicolumn{6}{|c|}{ Індекс Руф’', у.о. } \\
\hline Вихідні дані & $10,2 \pm 0,4$ & \multirow[t]{2}{*}{12,7} & $10,4 \pm 0,4$ & \multirow[t]{2}{*}{2,0} & 0,35 \\
\hline Кінцеві дані & $8,9 \pm 0,4$ & & $10,2 \pm 0,3$ & & 2,6 \\
\hline $\mathrm{t}$ & 2,32 & & 0,40 & & \\
\hline
\end{tabular}


Розглянемо більш детальніше результати дослідження життєвого індексу в групах юнаків.

На початку експерименту середні показники життєвого індексу (ЖІ) в юнаків ЕГ становили $52,5 \pm 1,8$ мл/кг, тоді як в юнаків КГ $-51,8 \pm 1,9$ мл/кГ $(\mathrm{t}=0,27, \mathrm{p}>0,05)$. Після впровадження експериментальної методики у групі юнаків ми спостерігаємо приріст у показниках ЖІ. Зокрема, середні показники в

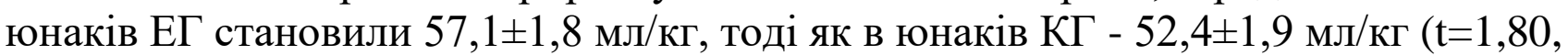
$\mathrm{p}>0,05)$. Варто відмітити, що між показниками цього тесту на початку дослідження $\mathrm{i}$ даними кінця експерименту достовірно між собою не відрізнялися у обох групах обстеження $(\mathrm{t}=0,22-1,78, \mathrm{p}>0,05)$.

Аналізуючи отримані результати силового індексу (CI) у обох групах дослідження ми також спостерігаємо зростання цих показників: в юнаків ЕГ

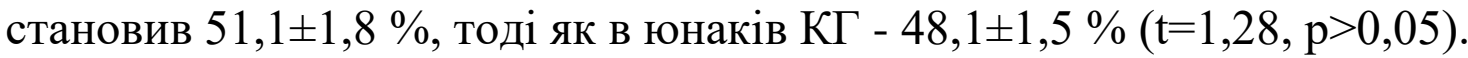

На II етапі дослідження показник СІ підвищився у юнаків ЕГ на $11,9 \%$ i становив, в середньому, $57,2 \pm 1,9 \%$, а в юнаків КГ показник підвищився лише на $2,1 \%$ i становив - 49,1 $\pm 1,6 \%(\mathrm{t}=3,25, \mathrm{p}<0,01)$. Достовірність різниці спостерігалася між показниками I та II етапів дослідження СI лише у ЕГ юнаків наприкінці, і становила на рівні $\mathrm{t}=2,33, \mathrm{p}<0,05$.

Аналізуючи отримані результати дослідження індексу Руф'є у обох групах обстеження ми також спостерігаємо покращення фізичної працездатності у юнаків обох груп. Слід відмітити, що спостерігається певне не рівномірне зростання показників у обох групах (Табл.2). Отримані показники індексу Руф'є обох груп між собою достовірно між собою не відрізнялися на I етапі $(\mathrm{t}=0,35$, $\mathrm{p}>0,05)$ і відрізнялися на II етапі тестування $(\mathrm{t}=2,6, \mathrm{p}<0,05)$.

Середній показник індексу Руф'є на початку дослідження у юнаків ЕГ

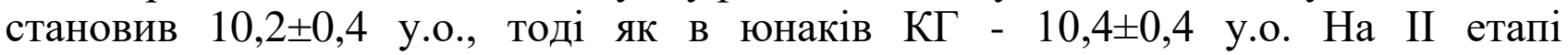
дослідження показник індексу Руф'є підвищився в юнаків, які займалися

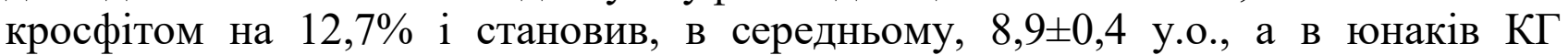
показник підвищився на 2,0\% і становив $10,2 \pm 0,3$ у.о.

При обробці отриманих результатів нами виявлено достовірні відмінності між показниками індексу Руф'є I та II етапів тестування лише у ЕГ юнаків $(\mathrm{t}=2,32, \mathrm{p}<0,05)$.

Висновки. Встановлено, що після впровадження секційних занять кросфітом відбувається достатній приріст всіх показників силової підготовленості в юнаків експериментальної групи порівняно з показниками юнаків контрольної групи, зокрема у підтягуванні на перекладині на 20,4\%, у згинанні і розгинанні рук в упорі лежачи на $14,6 \%$, підніманні тулуба в сід за 30 с на $24,8 \%$, та кистьової динамометрії на $16,7 \%$.

Середньостатистичні показники рівня силової підготовленості юнаків, які відвідували секцію 3 кросфіту на другому етапі обстеження у всіх випадках достовірно відрізняються від аналогічних показників юнаків на першому етапі обстеження $(\mathrm{t}=2,21-2,30, \mathrm{p}<0,05)$.

3'ясовано, що систематичні заняття в секції 3 кросфіту позитивно впливають на фізичний розвиток, який вивчали за результатами індексів, у групі 
юнаків. Фізичні навантаження на тренуваннях 3 кросфіту сприяли покращенню показника життєвого індексу на 8,8\%, показника силового індексу на 11,9\% та індексу Руф'є на 12,7\%. Достовірні різниці між показниками першого та другого етапів обстеження у групі юнаків, що займалися кросфітом спостерігалися за силовим індексом $(\mathrm{t}=2,33, \mathrm{p}<0,05)$ та індексом Руф'є $(\mathrm{t}=2,32, \mathrm{p}<0,05)$.

\section{Лimepamypa:}

1. Базилевич Н.О., Тонконог О.С. Особливості використання нового виду спорту «Crossfit» у самостійній фізкультурно-оздоровчій роботі студентів. Гуманітарний Вісник ДВНЗ «Переяслав-Хмельницький ДПУ імені Григорія Сковороди». Спецвипуск. ПереяславХмельницький, ФОП Лукашевич О.М., 2016. С. 136-142.

2. Бесараб Т., Герасімов О. Кросфіт як форма організації фізичних навантажень, що спрямовані на розвиток функціональних можливостей та силових здібностей людини. Сучасні фітнес-технології у фізичному вихованні студентів : матеріали IV Міжнар. наук.практ. конф. студентів, аспірантів і молодих учених; за заг. ред. В. В. Білецької. Т. І. Київ : HAУ, 2015. C.82.

3. Кім Р. А. Організаційно-методичні аспекти розвитку силових якостей у старшокласників у позаурочній секції з кросфіту : кваліфікаційна робота на здобуття ступеня вищої освіти «магістр» ; наук. керівник к.п.н., доц. В.Ю.Коваль. Херсон : ХДУ, 2020. 57 с. Режим доступу: http://eKhSUIR.kspu.edu/123456789/12559

4. Кокорев, Д. А., Выприков Д.В., Везеницин О.В., Бодров И.М. Методика использования функционального многоборья (кроссфита) в процессе физического воспитания студентов. Теория и практика физической культуры. 2016. №. 9. С. 16-18. https://cyberleninka.ru/article/n/metodika-ispolzovaniya-funktsionalnogo-mnogoborya-krossfita-vprotsesse-fizicheskogo-vospitaniya-studentov/viewer

5. Круцевич Т.Ю., Воробйов М.І., Безверхня Г.В. Контроль у фізичному вихованні дітей, підлітків і молоді. К.: Олімпійська література, 2011. 224 с.

6. Петрова А. Вплив вправ кросфіту на рівень фізичної підготовленості школярів старшого шкільного віку. Слобожанський науково-спортивний вісник, 2021. №2(82). С. 63-69. https://www.researchgate.net/publication/351847069_Vpliv_vprav_krosfitu_na_riven_fizicnoi_pidg otovlenosti_skolariv_starsogo_skilnogo_viku

\section{References:}

1.Bazylevich, N.O. \& Tonkonog, O.S. (2016) Osoblyvosti vykorystannia novogo vydu sportu «Crossfit» u samostiyniy fizkulturno-ozdorovchiy roboti studentiv [Features of the use of a new sport "Crossfit" in the independent physical culture and health work of students]. Gumanitarnyy Visnyk DVNZ "Pereyaslav-Hkmelnyckyy" DPU imeni Grygoriya Skovorody". Specvypusk. Humanitarian Bulletin of Pereyaslav-Khmelnytjky State Pedagogical University named after Hryhoriy Skovoroda. Special issue. 136-142 [in Ukrainian].

2. Besarab, T. \& Gerasimov, O. (2015) Krosfit yak forma organizacii fizychnyh navantajen, scho spryamovani na rozvytok funkcionalnyh mojlyvostey ta zdibnostey lyudyny [Crossfit as a form of organization of physical activity aimed at the development of functional capabilities and strengths of human]. Suchasni fitness-tehnologii u fizychnomu vyhovanni studentiv : materialy IV Mijnanar.-nauk.prakt. konf.studentiv, aspirantiv $i$ moloduh uchenyh ; za zag. red. V.V.Bileckoi - Modern fitness technologies in physical education of students: materials of the IV International. scientific-practical conf. students, graduate students and young scientists; for the head ed. VV Biletskaya. 82 [in Ukrainian].

3. Kim, R.A. (2020) Organizaciyno-metodychni aspekty rozvytku sylovyh yakostey u starschoklasnykiv u pozaurochniy sekcii z krosfitu [Organizational and methodological aspects of the development of strength qualities in high school students in the extracurricular crossfit section]. 
Kvalifikaciyna robota na zdobuttya stupenia vyschoyi osvity «magistr»; nauk.kerivnyk k.p.n., doc. V.Yu.Koval - qualification work for the degree of "master"; Science. Head Ph.D., Assoc. VYu Koval. Kherson : KhSU, Retrieved from http://eKhSUIR.kspu.edu/123456789/12559 [in Ukrainian]

4. Kokoryev, D.A., Vyprikov, D.V., Vezenicyn, O.V. \& Bodrov, I.M. (2016) Metodika ispolzovania funkcionalnogo mnogoboriya (krossfita) v proccese fizicheskogo vospitaniya studentov [Methods of using functional all-around (crossfit) in the process of physical education of students] Teoriya $i$ praktika fizicheskoy kultury. 9, 16-18 Retrieved from https://cyberleninka.ru/article/n/metodika-ispolzovaniyafunktsionalnogo-mnogoborya-krossfita-v-protsesse-fizicheskogo-vospitaniya-studentov/viewer [in Russian].

5. Krucevych, T.Yu., Vorobyov, M.I. \& Bezverhniya, G.V. (2011) Kontrol u fizychnemy vyhovanni ditey, pidlitkiv i molodi [Control in physical education of children, adolescents and young people]. Kyiv, Olympic literature. [in Ukrainian].

6. Petrova, A. (2021) Vplyv vprav krosfiru na riven fizychnoyi pidgotovlenosti scholyariv starschogo schkilnogo viku [The influence of crossfit exercises on the level of physical fitness of high school students]. Slobojanscyyi nauko-sportyvnyyi visnyk - Slobozhansky scientific and sports bulletin, 2 (82). 63-69. Retrieved from https://www.researchgate.net/publication/351847069_Vpliv_vprav_ krosfitu_na_riven_fizicnoi_pidgotovlenosti_skolariv_starsogo_skilnogo_viku [in Ukrainian]. 